\title{
Inhibitory Activity and Docking Analysis of Antimalarial Agents from Stemona sp. toward Ferredoxin-NADP+ Reductase from Malaria Parasites
}

\author{
Pratiwi Pudjiastuti (D), ${ }^{1}$ Ni Nyoman T. Puspaningsih, ${ }^{1}$ Imam Siswanto, ${ }^{1}$ Much. Z. Fanani, ${ }^{2}$ \\ Yoko K. Ariga, ${ }^{3}$ Toshiharu Hase, ${ }^{4}$ Satyajit D. Sarker, ${ }^{5}$ and Lutfun Nahar $\mathbb{D}^{5}$ \\ ${ }^{1}$ Department of Chemistry, Faculty of Science and Technology, Airlangga University, Surabaya 60115, Indonesia \\ ${ }^{2}$ Laboratory of Proteomics, Institute of Tropical Disease, Airlangga University, Surabaya 60115, Indonesia \\ ${ }^{3}$ Graduate School of Sciences and Technology for Innovation, Department of Agriculture, Yamaguchi University, \\ Yamaguchi 753-8515, Japan \\ ${ }^{4}$ Institute of Protein Research, Osaka University, 3-2 Yamadoaka, Suita-shi, Osaka 656-0871, Japan \\ ${ }^{5}$ Medicinal Chemistry and Natural Products Research Group, School of Pharmacy and Biomolecular Sciences, \\ Liverpool John Moores University, James Parsons Building, Byrom Street, Liverpool L3 3AF, UK
}

Correspondence should be addressed to Pratiwi Pudjiastuti; pratiwi-p@fst.unair.ac.id

Received 16 March 2018; Revised 18 July 2018; Accepted 12 August 2018; Published 26 August 2018

Academic Editor: José F. Silveira

Copyright (C) 2018 Pratiwi Pudjiastuti et al. This is an open access article distributed under the Creative Commons Attribution License, which permits unrestricted use, distribution, and reproduction in any medium, provided the original work is properly cited.

Ferredoxin-NADP ${ }^{+}$reductases (FNRs, EC 1.18.1.2) were found in the plastids of Plasmodium and have been considered as a target for the development of new antimalarial agents. Croomine, epi-croomine, tuberostemonine, javastemonine A, and isoprotostemonine are isolated alkaloids from the roots of Stemona sp. and their inhibitory effect on FNRs from Plasmodium falciparum (PfFNR) was investigated. Croomine showed the highest level of inhibition (33.9\%) of electron transfer from $P f F N R$ to $P f F d$, while tuberstemonine displayed the highest level of inhibition (55.4\%) of diaphorase activity of $P f \mathrm{FNR}$. Docking analysis represented that croomine is located at the middle position of $P f F N R$ and $P f F d$. Croomine from S. tuberosa appeared to have potential as an antimalarial agent.

\section{Introduction}

Malaria is still considered as a threat in the world, especially in Asia and Africa. Almost 97 countries in the world are malaria endemic. More than 3.3 billion people (almost 50\% of the world's population) are at risk of malaria with two Plasmodium species responsible for the majority of infections: P. falciparum and P. vivax [1]. Many antimalarial agents, such as chloroquine, pyrimethamine, quinine, proguanil sulfadoxine, and artemisinin have been used for malarial therapy. Artemisinin, the first-line antimalarial drug has been used against $P$. falciparum in Cambodia, Thailand, Vietnam, and Myanmar, where artemisinin-resistant parasites have already been identified [1]. In Papua, Indonesia, resistance to artemisinin derivatives, artesunate and dihydroartemisinin, and semisynthetic 10-alkylamino-artemisinin derivatives, artemisone and artemiside, has also been observed in $P$. falciparum [2]. Ratcliff, et al. (2007) studied 143 patients (103 and 40 patients) who were treated with chloroquinesulfadoxine and chloroquine, respectively. The failure rate at 28 and 42 days was $65 \%$ and $48 \%$ for $P$. falciparum and $P$. vivax, respectively [3]. Pyrimethamine and sulfadoxine can inhibit dihydrofolate reductase (DHFR) and dihydropteroate synthase (DHPS) enzymes. These enzymes undergo gene mutations causing the resistance of antimalarial antifolate [4]. Double and quadruple mutations in the $P$. vivax dihydrofolate reductase ( $P v \mathrm{DHFR}$ ) found in Papua $P$. vivax isolates were 46 and $18 \%$, respectively [5].

Plasmodium sp. has a unique organelle, called apicoplast, and it possesses metabolic pathways, which is not found 


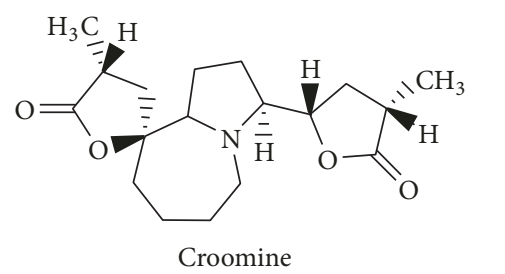

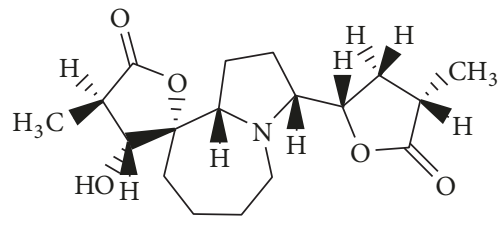

Epi-croomine

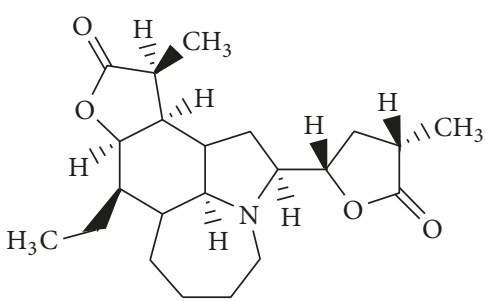

Tuberostemonine

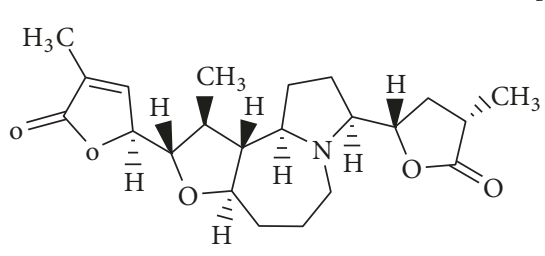

Isoprotostemonine<smiles>COC1=C(C)C(=O)O/C1=C1\O[C@@H]2CCCN[C@H]3[C@@H]1[C@@H]2[C@H]3C1C[C@H](C)C(=O)O1</smiles>

Javastemonine A

Figure 1: Structure of alkaloids from the roots of Stemona sp.

in human host $[6,7]$. The apicoplast was firstly found in P. falciparum and Toxoplasma [8]. The function of plastid (apicoplast) in Apicomplexa is unclear, but many studies suggested its roles in the biosynthesis of fatty acids, haem, isoprenoids, and Fe-S cluster, based on the analysis of genome sequence. More importantly, the metabolism of apicoplast is necessary for the survival of the Plasmodium $[6,9,10]$.

Ferredoxin $(\mathrm{Fd})$ and $\mathrm{Fd}-\mathrm{NADP}^{+}$reductase (FNR) in apicoplast constitute a redox system $[11,12]$ that is homologous to those of plant chloroplast and algae, especially green and red algae $[8,13]$.The involvement of apicoplast $\mathrm{Fd}$ has been indicated in the reactions of an Fe-S cluster assembly [14] and isoprenoid biosynthesis pathways [10, 15], fatty acid desaturation [5], and heme oxygenation [16].

In a previous study, in silico analysis showed that croomine and epi-croomine could form hydrogen bonds with the amino acid residue of Ala9 of the DHFR enzyme [17]. DHFR can be found in human and Plasmodium, but FNR is found only in Plasmodium. Fd and FNR were cloned from $P$. falciparum and their interactions were characterized $[9,18]$. There has been no report on plant-alkaloid inhibiting FNR available to date. Here, we describe the inhibitory effect of alkaloids from the roots of Stemona sp. on the PfFd/FNR redox system, and the results of their docking analysis.

\section{Materials and Methods}

2.1. Isolation of Alkaloid from Stemona Species. The dry roots of $S$. tuberosa were cut in small size and ground into powder and extracted using ethanol. The filtrate was evaporated under vacuum and extracted by acid based method using 5\% of $\mathrm{HCl}$ and conc of $\mathrm{NH}_{4} \mathrm{OH}$. Water fraction was partitioned using dichloromethane (DCM) and evaporated. The crude alkaloid was separated using column chromatography under silica gel as stationary phase and DCM-methanol as mobile phase with polarity gradient elution. The alkaloids were purified using preparative chromatography to give tuberostemonine, croomine, and epi-croomine (epi-10-hydroxycroomine or 3-epi-tuberospironine A) [19].
Isolation of isoprotostemonine and javastemonine $\mathrm{A}$ from $S$. javanica utilized the same method as described for the isolation of alkaloids from $S$. tuberosa. Previous study exhibited that tuberostemonine, croomine, and epi-croomine were treated to antifolate target of DHFR enzymes. Isoprotostemonine and javastemonine A from S. javanica were carried out against $P$. falciparum multidrug resistant and wild type parasites at Medical Molecular Research Unit, Thailand Science Park, Pathumthani, Thailand [20]. The structures of alkaloids were shown in Figure 1. Five alkaloids were made as $1000 \mathrm{ppm}$ stock solution (in $0.2 \%$ of DMSO in suspension of phosphate buffer at $\mathrm{pH}$ 7.0). The final alkaloids solution concentration was $100 \mathrm{ppm}$.

2.2. Preparation of Recombinant PfFNR and PfFd. Production and purification of recombinant $P f F d$ and $P f$ FNR were performed as reported by Kimata-Ariga et al. [9].

2.3. Enzymatic Activity Analysis. Enzyme activity of $P f$ FNR was measured using a grating microplate reader (model SH1000Lab, CORONA, Japan). Diaphorase activity of FNR with DCPIP as an electron acceptor (Scheme 1) was measured as reported by Onda [21] with modification in the reaction mixture of $50 \mathrm{mM}$ Tris- $\mathrm{HCl}$ ( $\mathrm{pH} 7.5), 1 \mathrm{mM} \mathrm{MgCl}, 0.2 \mathrm{mM}$ DCPIP, and $5 \mathrm{nM}$ FNR. The reaction was initiated by adding 5-100 $\mu \mathrm{M}$ of NADPH and the decrease of the absorbance was monitored for $5 \mathrm{~min}$ with 10 -second intervals at $600 \mathrm{~nm}$. The activity of NADPH-dependent electron transfer from FNR to Fd (Scheme 2) was measured using cytochrome $c$ (cyt $c$ ) as an arbitrary electron acceptor as reported by Onda [21] with modification in the reaction mixture of $50 \mathrm{mM}$ Tris- $\mathrm{HCl}$ (pH 7.5), $100 \mathrm{mM} \mathrm{NaCl}, 200 \mu \mathrm{M}$ cytc, and $10 \mathrm{nM}$ $P f$ FNR. Electron transfer reaction was initiated by adding 0.5-40 $\mu \mathrm{M} P f \mathrm{Fd}$ and $100 \mu \mathrm{M} \mathrm{NADPH}$, and the absorbance was monitored for $5 \mathrm{~min}$ with 10 -second intervals at $550 \mathrm{~nm}$. The kinetic parameters for the Michaelis constant $\left(K_{m}\right)$ for these reactions were determined. 
Scheme 1 (NADPH $\rightarrow$ FNR $\rightarrow$ DCPIP). Scheme 1 is used for measuring the NADPH-dependent catalytic activity of FNR.

Scheme 2 (NADPH $\rightarrow$ FNR $\rightarrow$ Fd $\rightarrow$ cytc). Scheme 2 is used for measuring the NADPH-dependent electron transfer activity from FNR to Fd.

2.4. Inhibition Assay. Inhibition of diaphorase activity of PfFNR was measured in the reaction of Scheme 1 as described above, by the additions of each alkaloid at $100 \mathrm{ppm}$, $\mathrm{NADPH}$ at $100 \mathrm{uM}$, and $5 \mathrm{nM}$ FNR. Inhibition of the electron transfer from $P f F N R$ to $P f F d$ was measured in the reaction of Scheme 2 as described above, by the additions of each alkaloid at $100 \mathrm{ppm}$ and $P f \mathrm{Fd}$ at $1 \mu \mathrm{M}$. A $5 \mathrm{mM}$ solution of DMSO was used as a control.

2.5. Docking Procedures. Molecular docking was performed using Dock 6.8 software (http://dock.compbio.ucsf.edu/ DOCK_6/index.htm) [22]. Docking studies were carried out on an Intel Core i5 $2.4 \mathrm{GHz}$ PC, with $16 \mathrm{~GB}$ memory and with Windows 10 operating system.

\section{Ligand and Receptor Preparations}

The receptor model was obtained from Protein Data Bank (PDB) server (http://www.rcsb.org/) with ID 1GAQ [23]. This complex consists of three chains, there are enzyme Plasmodium falciparum (PfFNR), flavin adenine dinucleotide (FAD), and some crystals of water. Crystals of water were not involved in the reaction mechanism directly and were stripped out from the complex. In contrary, FAD was used as a part of the receptor. Hydrogen and charge atoms were added to $P f F N R$ and FAD complex using molecular mechanics method with AMBERff14SB force field [24]. Hydrogen atom was stripped out from $P f F N R$ and hydrogen-free $P f F N R$ was saved in pdb format to generate molecular surface of the receptor.

Ligand models were drawn using HyperChem6 software of HyperCube, Inc (http://www.hyper.com/). All the ligand models were preoptimized using MM+ molecular mechanics methods before being optimized utilizing semiempirical method AM1 to generate 3D conformation also in HyperChem 6 as final process. These optimized ligands were saved in MDL mol file format. Hydrogen and charge atoms were added and loaded using the AM1-BCC charge calculation [25] and UCSF Chimera (https://www.cgl.ucsf.edu/chimera/) [26] methods, respectively. All these protonated and charged ligands were saved in Sybil mol2 files format.

\section{Ligands Docking}

The molecular surface of the receptor was generated with the $\mathrm{dms}$ tools which was included in the DOCK 6.8 package program. The molecular surface was achieved by dms tool and spheres of the receptor were generated using program sphgen [27]. Binding site was represented by the largest cluster of the spheres generated of sphgen. Grid box for docking simulation was created around the binding site with extra margin $5 \AA$. Grid space was set in $0.2 \AA$, while the dimension is

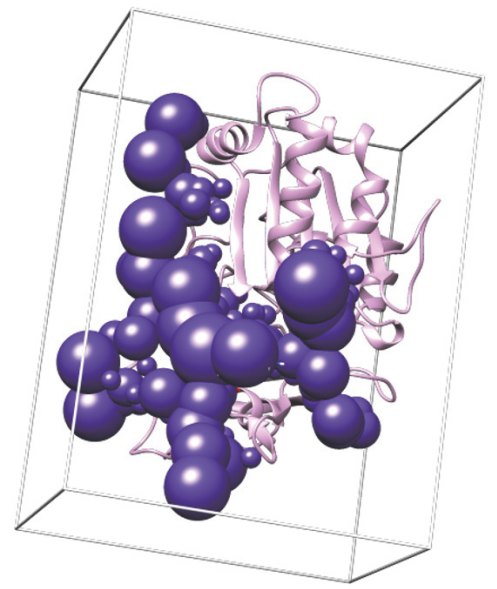

FIGURE 2: Selected cluster sphere of the receptor as the representation of the binding site is inside the grid box.

TABLE 1: Inhibition (\%) of NADPH-dependent catalytic activity of PfFNR.

\begin{tabular}{lcc}
\hline Alkaloids $*$ & $\mathrm{dA} / \mathrm{dt} * *$ & \% Inhibition \\
\hline Control & 0.059 & - \\
Croomine & 0.039 & 33.9 \\
Epi-croomine & 0.059 & 0.7 \\
Tuberstemonine & 0.052 & 11.5 \\
Isoprotostemonine & 0.088 & -48.8 \\
Javastemonine A & 0.065 & -9.5 \\
\hline
\end{tabular}

$*$ Each of alkaloids is $100 \mathrm{ppm} ; * \mathrm{dA} / \mathrm{dt}$ is the rate of absorbance change.

$47.814 \AA$ x $63.571 \AA$ x $39.732 \AA$. The location of the largest cluster of the spheres as the representation of the binding site and grid box on the receptor was shown in Figure 2. Each ligand was docked within the binding site of the receptor using Dock 6.8 resulting in binding (Grid_score) and van der Waals (Grid_vdw) energies, electrostatic interaction (Grid_es), and internal energy of the complex (Int_energy). Int_energy was determined based on force of field energy calculated.

\section{Results and Discussion}

The structures of alkaloids from the roots of Stemona species are shown in Figure 1.

5.1. Inhibition of NADPH-Dependent Catalytic Activity of PfFNR by Alkaloids from the Stemona sp. The effect of these alkaloids from the roots of Stemona spp. (Figure 1) on the NADPH-dependent catalytic activity (diaphorase activity) of $P f$ FNR (Table 1) was inquired. In this reaction, the effects on the FNR catalytic activity and/or interaction with NADPH were to be considered. In the absence of the inhibitors, the $K_{m}$ value for NADPH was $3.57 \mu \mathrm{M}$. The inhibition assay was performed under the same conditions used in the $K_{m}$ determination employing the following conditions: the concentration of NADPH was $100 \mu \mathrm{M}$, the concentration of $P f$ FNR was $5 \mathrm{nM}$, and the concentration of tested compounds 
TABLE 2: Inhibition of diaphorase activity of $P f F N R$.

\begin{tabular}{lcc}
\hline Alkaloids $*$ & $\mathrm{dA} / \mathrm{dt} * *$ & \% Inhibition \\
\hline Control & 0.139 & - \\
Croomine & 0.138 & 0.7 \\
Epi-croomine & 0.122 & 12.2 \\
Tuberstemonine & 0.062 & 55.4 \\
Isoprotostemonine & 0.17 & -22.3 \\
Javastemonine A & 0.144 & -3.6 \\
\hline
\end{tabular}

$*$ Each of alkaloids is $100 \mathrm{ppm} ; * \mathrm{dA} / \mathrm{dt}$ is the rate of absorbance change.

was $100 \mathrm{ppm}$. The \% inhibition was calculated according to the following equation, and the results are listed in Table 1.

$$
\begin{aligned}
\% \text { Inhibition }= & \frac{(d A / d t) \text { control }-(d A / d t) \text { sample }}{(d A / d t) \text { control }} \\
& \times 100 \%
\end{aligned}
$$

The results showed that three out of the five tested compounds were able to inhibit the reaction by between 0.7 and $33.9 \%$, while the other two compounds exhibited a negative inhibition, which means that these compounds accelerated the activity. Croomine alkaloid showed 33.9\%, the largest inhibition, and epi-croomine showed lower but considerable inhibition. Isoprotostemonine and javastemonine A exhibited a negative inhibition. This might be because both alkaloids have double bonds conjugated to carbonyl group and, thus, might considerably trigger electron delocalization and stabilisation of resonance. Stabilisation of resonance in isoprotostemonine and javastemonine $\mathrm{A}$, which means that these compounds accelerated the electron transfer from PfFNR to PfFd, will make P. falciparum parasites live because electron transfer occurs in respiratory process [28].

\subsection{Inhibition of the Electron Transfer from PfFNR to PfFd by} Alkaloids from the Stemona sp. The effect of alkaloids from the roots of Stemona sp. (Figure 1) on the electron transfer from $P f$ FNR to $P f F d$ (Table 2) was investigated. In the absence of the inhibitors, the $K_{m}$ value of $P f \mathrm{FNR}$ for $P f \mathrm{Fd}$ was $0.56 \mu \mathrm{M}$, which was consistent with previous studies [28]. The inhibition assay was performed under the same conditions used in the $K_{m}$ determination employing the following conditions: the concentration of $P f F d$ was $1 \mu \mathrm{M}$, the concentration of PfFNR was $10 \mathrm{nM}$, and the concentration of tested compounds was $100 \mathrm{ppm}$. The \% inhibition was calculated according to (1) and the results are listed in Table 2.

In this case, the same three compounds inhibited the reaction, while the two compounds exhibited a negative inhibition, but to different extents as compared to the results in Table 1. Croomine showed the largest inhibition on the reaction the FNR activity and tuberstemonine showed slight inhibition. This could be due to the inhibition of either FNR catalysis or NADPH binding to FNR. Croomine was previously shown to inhibit the activity of dihydrofolate reductase (DHFR, an enzyme for antifolate drug mechanism). The $\mathrm{IC}_{50}$ of croomine to the DHFR was $5.29 \mu \mathrm{M}$, while tuberostemonine was not active to the enzyme [17].
Ramli et al. (2015) reported that isoprotostemonine and javastemonine $\mathrm{A}$ have low to in active against multidrug resistant $\mathrm{K} 1 \mathrm{CB} 1$ and wild type and antifolate strains of $P$. falciparum parasites in vitro [20]. On the other hand, isoprotostemonine and javastemonine A showed negative inhibition and they accelerated FNR reaction. The javastemonine A exhibited moderate activities against $P$. falciparum TM4 and $\mathrm{KI}$ strains with $\mathrm{IC}_{50}$ of 17.7 and $16.8 \mathrm{ppm}$, respectively [20].

The diaphorase activity of $P f F N R$ in the presence of the Stemona alkaloids at $100 \mathrm{ppm}$ is shown in Table 2. In this case, tuberostemonine alkaloids showed the highest inhibition and epi-croomine showed slight inhibition. Tuberostemonine could inhibit electron transfer process of PfFNR to $P f \mathrm{Fd}$ enzyme. Isoprotostemonine and javastemonine A again exhibited a negative inhibition, because both alkaloids have double bonds conjugated to carbonyl group. Isoprotostemonine and javastemonine A could be considered as trigger electron delocalization and stabilisation of resonance.

5.3. Docking Analysis of Alkaloids toward Protein. The interaction between the alkaloids from the Stemona sp. and PfFd$P f$ FNR was studied by molecular docking. The structure of PfFNR was obtained from the Protein Data Bank (PDBID 1GAQ)[23]. Five alkaloids from Stemona sp. were expected to bind to $P f F N R$. Figure 2 showed the location of the largest cluster of the spheres as the representation of the binding site and grid box on the receptor. This result indicated that the parameters used in the procedure could be extended to search for the binding conformation to the active site for the other ligands (alkaloids). Figure 3 showed that interaction between receptors of $P f F d$ (blue), $P f F N R$ (brown), and ligand (red). $\mathrm{FAD}$ (green) is not involved in bonding receptors-ligand.

Electron transfer is going on in Plasmodium from $P f F N R$ to $P f F d$ through electrostatics interaction during respiration process [9]. Position of croomine displayed at the middle between $P f$ FNR and $P f F d$, while epi-croomine, tuberostemonine, isoprotostemonine, and javastemonine A were on the edge of the receptors (Figure 3 ). Croomine showed inhibition $33 \%$, which was higher than tuberostemonine and epicroomine. Croomine could obstruct electron transfer from $P f F N R$ to $P f F d$. This result was supported by research report foregoing that croomine inhibited competitively the human DHFR enzyme at $10 \mathrm{ppm}$ [17].

Tuberostemonine is stenine alkaloid, while croomine and epi-croomine are spironine, and isoprotostemonine and javastemonine A are stemoamide alkaloids types [29]. The characteristic of stenine type is 4-fused rings in its structure, and spironine type has only 2 -fused rings. $\mathrm{N}$ atom in 4 -fused rings structure is rigid and stable. It is likely that the $\mathrm{N}$ atom in 4-fused ring is important for the diaphorase activity.

\section{Conclusions}

Croomine could inhibit the activity of FNR enzyme and electron transfer from $P f F N R$ to $P f F d$. Thus, croomine from $S$. tuberosa appeared to have potential as an antimalarial agent. Tuberostemonine inhibited diaphorase for redox reaction. 


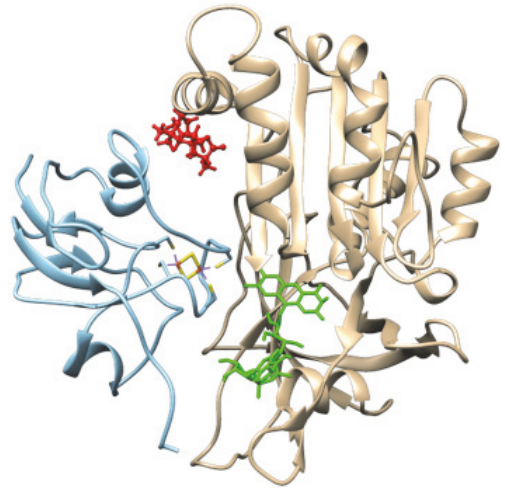

(a)

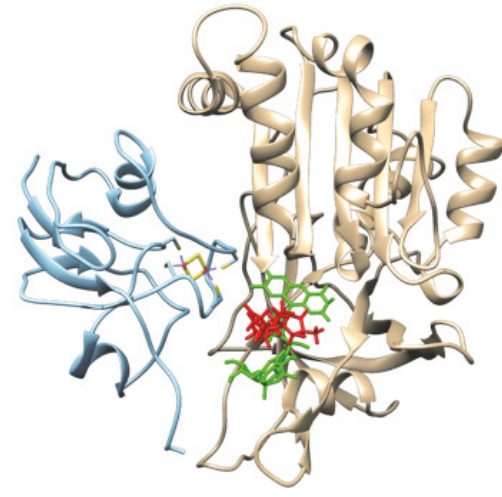

(b)

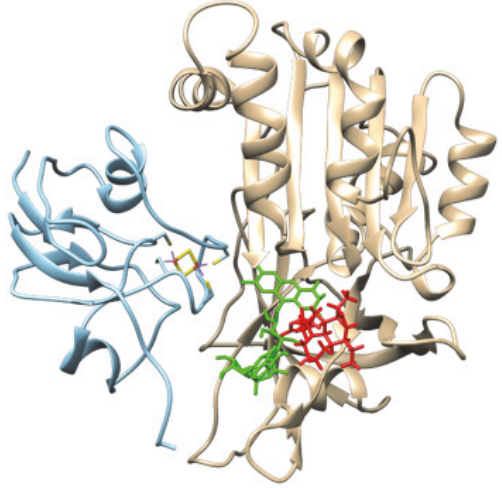

(c)

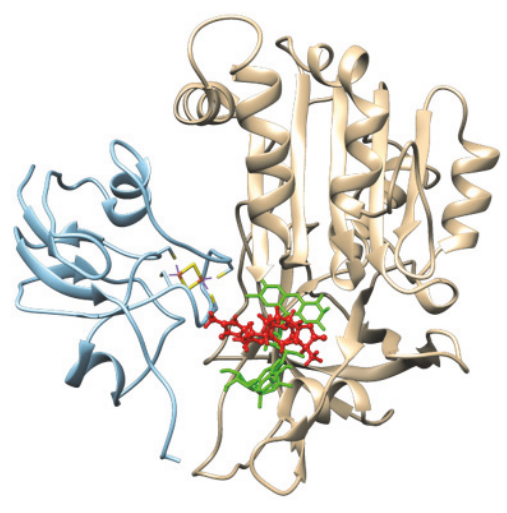

(d)

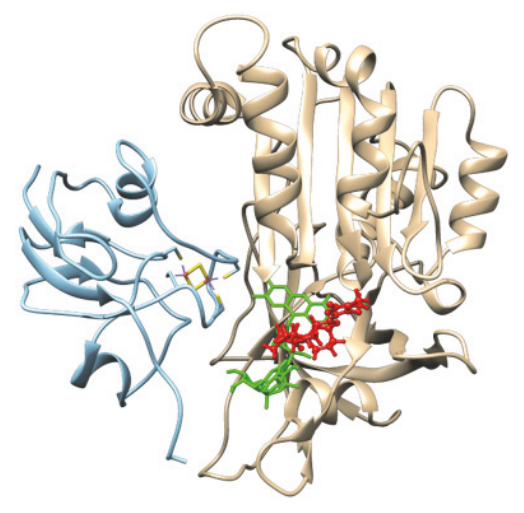

(e)

FiguRE 3: Interaction between receptors of Fd (blue), FNR (brown), and ligand (red): (a) croomine, (b) Epi-croomine, (c) tuberstemonine, (d) isoprotostemonine, and (e) javastemonine A.

\section{Data Availability}

The data used to support the findings of this study are available from the corresponding author upon request.

\section{Conflicts of Interest}

The authors declare that there are no conflicts of interest.

\section{Authors' Contributions}

The authors contributed equally in isolation and inhibition of enzyme activities, molecular docking, and writing of this paper.

\section{Acknowledgments}

The research was funded by Penelitian Unggulan Perguruan Tinggi (PUPT), Ministry of Research, Technology and Higher Education, Indonesia, in FY 2016. We thank Prof. Stephen G. Pyne and Dr. Wilford Lie from School of Chemistry, University of Wollongong, Wollongong, NSW, Australia, for spectroscopic measurement.

\section{References}

[1] World Health Organization, World Malaria Report 2014, World Health Organization, Geneva, Switzerland, 2014.
[2] J. Marfurt, F. Chalfein, P. Prayoga et al., "Comparative ex vivo activity of novel endoperoxides in multidrug-resistant Plasmodium falciparum and P. vivax," Antimicrobial Agents and Chemotherapy, vol. 56, no. 10, pp. 5258-5263, 2012.

[3] A. Ratcliff, H. Siswantoro, E. Kenangalem et al., "Therapeutic response of multidrug-resistant Plasmodium falciparum and $\mathrm{P}$. vivax to chloroquine and sulfadoxine-pyrimethamine in southern Papua, Indonesia," Transactions of the Royal Society of Tropical Medicine and Hygiene, vol. 101, no. 4, pp. 351-359, 2007.

[4] P. B. Boland, Drug Resistance in Malaria, World Health Organization: Department of Communicable Disease Surveillance and Response, Switzerland, 2001.

[5] E. Tjitra, J. Baker, S. Suprianto, Q. Cheng, and N. M. Anstey, "Therapeutic efficacies of artesunate-sulfadoxine-pyrimethamine and chloroquine-sulfadoxine-pyrimethamine in vivax malaria pilot studies: Relationship to Plasmodium vivax dhfr mutations," Antimicrobial Agents and Chemotherapy, vol. 46, no. 12, pp. 3947-3953, 2002.

[6] R. F. Waller and G. I. Mc Fadden, "The apicoplast: A review of the derived plastid of apicomplexan parasites," Current Issues in Molecular Biology, vol. 7, pp. 57-80, 2005.

[7] M. Vollmer, N. Thomsen, S. Wiek, and F. Seeber, "Apicomplexan parasites possess distinct nuclear-encoded, but apicoplastlocalized, plant-type ferredoxin-NADP+ reductase and ferredoxin," The Journal of Biological Chemistry, vol. 276, no. 8, pp. 5483-5490, 2001.

[8] N. M. Fast, J. C. Kissinger, D. S. Roos, and P. J. Keeling, "Nuclearencoded, plastid-targeted genes suggest a single common origin 
for apicomplexan and dinoflagellate plastids," Molecular Biology and Evolution, vol. 18, no. 3, pp. 418-426, 2001.

[9] Y. Kimata-Ariga, T. Saitoh, T. Ikegami, T. Horii, and T. Hase, "Molecular interaction of ferredoxin and ferredoxin-NADP+ reductase from human malaria parasite," The Journal of Biochemistry, vol. 142, no. 6, pp. 715-720, 2007.

[10] R. C. Röhrich, N. Englert, K. Troschke et al., "Reconstitution of an apicoplast-localised electron transfer pathway involved in the isoprenoid biosynthesis of Plasmodium falciparum," FEBS Letters, vol. 579, no. 28, pp. 6433-6438, 2005.

[11] D. Crobu, G. Canevari, M. Milani et al., "Plasmodium falciparum ferredoxin-NADP+ reductase His286 plays a dual role in $\mathrm{NADP}(\mathrm{H})$ binding and catalysis," Biochemistry, vol. 48, no. 40, pp. 9525-9533, 2009.

[12] S. Baroni, V. Pandini, M. A. Vanoni, and A. Aliverti, "A single tyrosine hydroxyl group almost entirely controls the NADPH specificity of plasmodium falciparum ferredoxinNADP+ reductase," Biochemistry, vol. 51, no. 18, pp. 3819-3826, 2012.

[13] G. I. McFadden and E. Yeh, "The apicoplast: now you see it, now you don't," International Journal for Parasitology, vol. 47, no. 2-3, pp. 137-144, 2017.

[14] F. Seeber, "Biogenesis of iron-sulphur clusters in amitochondriate and apicomplexan protists," International Journal for Parasitology, vol. 32, no. 10, pp. 1207-1217, 2002.

[15] G. S. Saggu, S. Garg, Z. R. Pala et al., "Characterization of 4-hydroxy-3-methylbut-2-en-1-yl diphosphate synthase (IspG) from Plasmodium vivax and it's potential as an antimalarial drug target," International Journal of Biological Macromolecules, vol. 96, pp. 466-473, 2017.

[16] K. Okada, "The novel heme oxygenase-like protein from Plasmodium falciparum converts heme to bilirubin IX $\alpha$ in the apicoplast," FEBS Letters, vol. 583, no. 2, pp. 313-319, 2009.

[17] P. Pudjiastuti, S. Sumarsih, H. Arwati et al., "Epi-croomine and croomine from Stemona tuberosa antimalarial drug for inhibiting dihydrofolate reductase (DHFR) activity and their molecular modeling," Journal of Chemical and Pharmaceutical Research, vol. 6, no. 6, pp. 544-548, 2014.

[18] Y. Kimata-Ariga, G. Kurisu, M. Kusunoki et al., "Cloning and characterization of ferredoxin and ferredoxin-NADP+ reductase from human malaria parasite," The Journal of Biochemistry, vol. 141, no. 3, pp. 421-428, 2007.

[19] P. Pudjiastuti, S. G. Pyne, Sugiyanto, and W. Lie, "Isolation of tuberospironine A, a novel croomine derivative from Stemona tuberosa Lour," Phytochemistry Letters, vol. 5, no. 2, pp. 358-360, 2012.

[20] R. A. Ramli, P. Pudjiastuti, T. S. Tjahjandaric et al., "Alkaloids from the roots of Stemona javanica (Kunth) Engl. (Stemonaceae) and their anti-malarial, acetylcholinesterase inhibitory and cytotoxic activities," Phytochemistry Letters, vol. 11, pp. 157-162, 2015.

[21] Y. Onda, T. Matsumura, Y. Kimata-Ariga, H. Sakakibara, T. Sugiyama, and T. Hase, "Differential interaction of maize root ferredoxin:NADP+ oxidoreductase with photosynthetic and non-photosynthetic ferredoxin isoproteins," Plant Physiology, vol. 134, no. 3, pp. 1037-1045, 2000.

[22] D. T. Moustakas, P. T. Lang, S. Pegg et al., "Development and validation of a modular, extensible docking program: DOCK 5," Journal of Computer-Aided Molecular Design, vol. 20, no. 10-11, pp. 601-619, 2006.
[23] G. Kurisu, M. Kusunoki, E. Katoh et al., "Structure of the electron transfer complex between ferredoxin and ferredoxinNAPD+ reductase," Nature Structural \& Molecular Biology, vol. 8, no. 2, pp. 117-121, 2001.

[24] J. Wang, W. Wang, P. A. Kollman, and D. A. Case, "Automatic atom type and bond type perception in molecular mechanical calculations," Journal of Molecular Graphics and Modelling, vol. 25, no. 2, pp. 247-260, 2006.

[25] E. F. Pettersen, T. D. Goddard, C. C. Huang et al., "UCSF Chimera-a visualization system for exploratory research and analysis," Journal of Computational Chemistry, vol. 25, no. 13, pp. 1605-1612, 2004.

[26] R. Wang, Y. Lu, and S. Wang, "Comparative evaluation of 11 scoring functions for molecular docking," Journal of Medicinal Chemistry, vol. 46, no. 12, pp. 2287-2303, 2003.

[27] I. D. Kuntz, J. M. Blaney, S. J. Oatley, R. Langridge, and T. E. Ferrin, "A geometric approach to macromolecule-ligand interactions," Journal of Molecular Biology, vol. 161, no. 2, pp. 269-288, 1982.

[28] H. Suwito, Jumina, Mustofa et al., "Design and synthesis of chalcone derivatives as inhibitors of the ferredoxin - Ferredoxin$\mathrm{NADP}^{+}$reductase interaction of Plasmodium falciparum: Pursuing new antimalarial agents," Molecules, vol. 19, no. 12, pp. 21473-21488, 2014.

[29] R. A. Philli, G. B. Rossoand, and M. C. F. De Oliveira, "The chemistry of stemona alkaloid: An update," Natural Product Reports, vol. 27, pp. 1908-1937, 2010. 


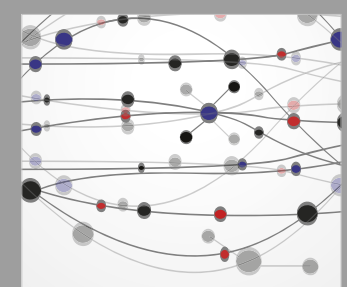

The Scientific World Journal
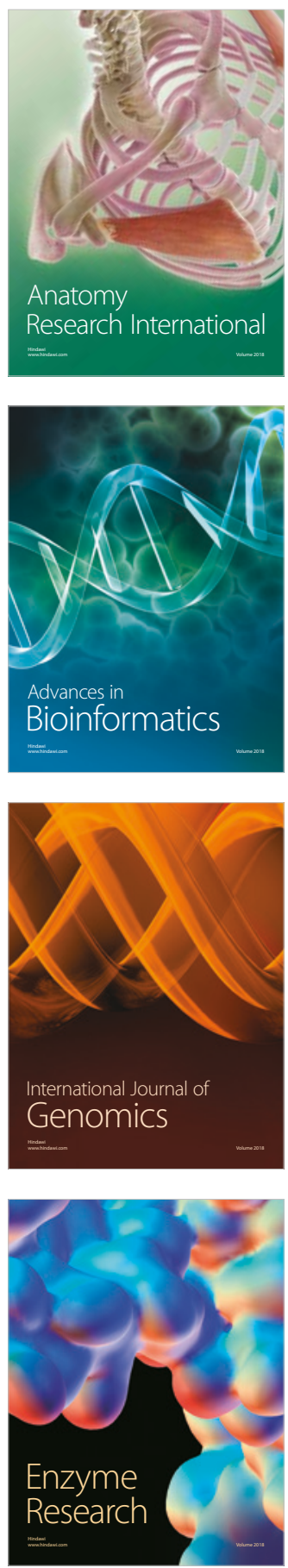
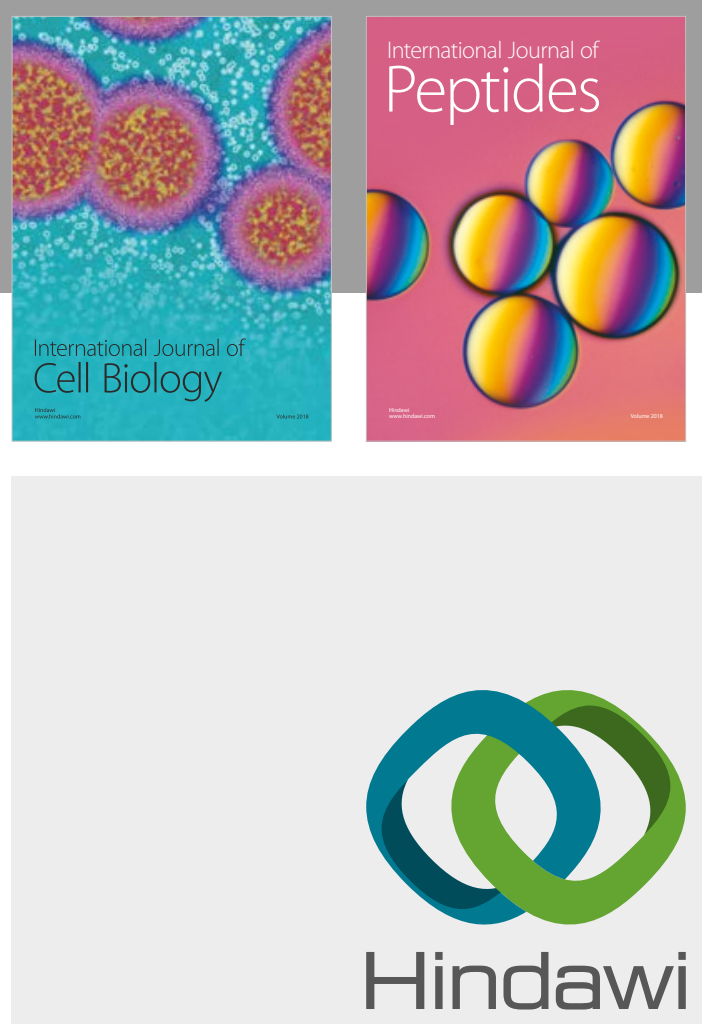

Submit your manuscripts at

www.hindawi.com
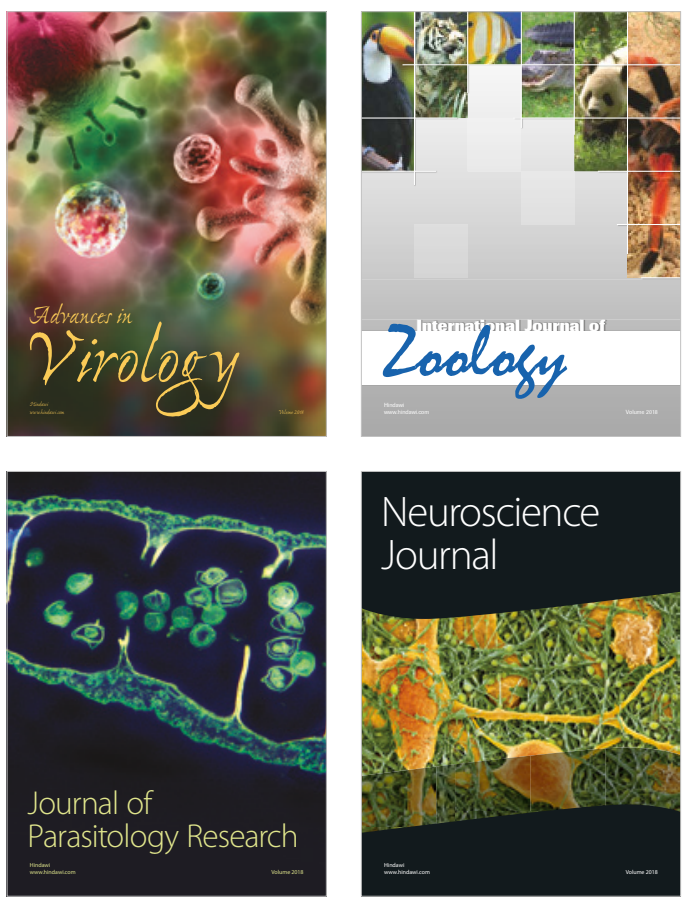
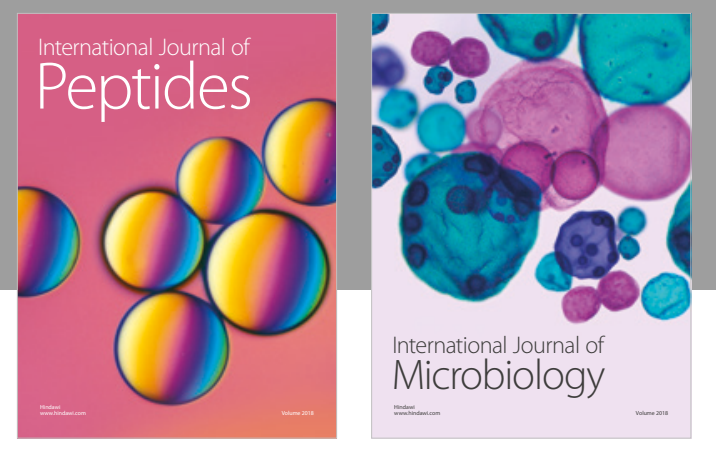

nternational Journal of Microbiology
Journal of
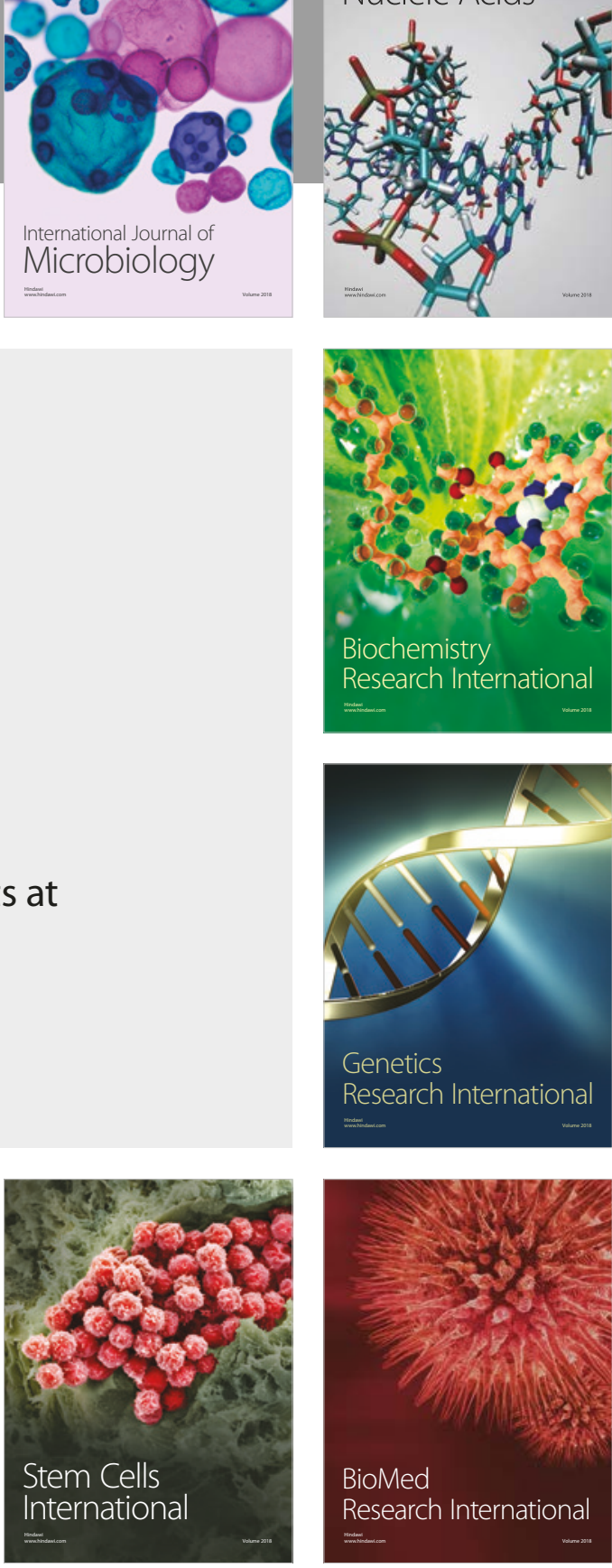
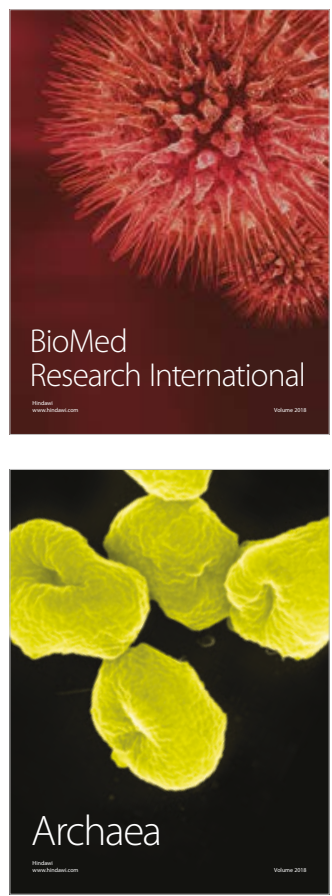